\title{
Transdermal testosterone replacement therapy in men
}

This article was published in the following Dove Press journal:

Drug Design, Development and Therapy

9 January 2014

Number of times this article has been viewed

\author{
M Iftekhar Ullah' \\ Daniel M Riche ${ }^{1,2}$ \\ Christian A Koch ${ }^{1,3}$ \\ 'Department of Medicine, University \\ of Mississippi Medical Center, \\ ${ }^{2}$ Department of Pharmacy Practice, \\ The University of Mississippi, \\ ${ }^{3} \mathrm{GV}$ (Sonny) Montgomery VA \\ Medical Center, Jackson, MS, USA
}

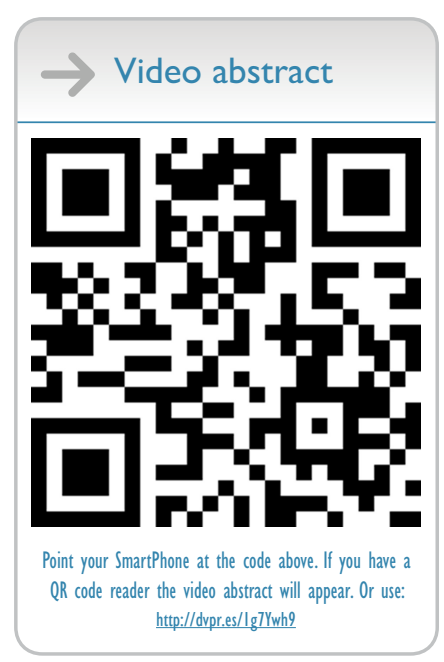

Correspondence: CA Koch; M Iftekhar Ullah

Department of Medicine, University of Mississippi Medical Center, $2500 \mathrm{~N}$ State Street, Jackson, MS 39216 , USA Email ckoch@umc.edu;

mullah@umc.edu

\begin{abstract}
Androgen deficiency syndrome in men is a frequently diagnosed condition associated with clinical symptoms including fatigue, decreased libido, erectile dysfunction, and metabolic syndrome. Serum testosterone concentrations decline steadily with age. The prevalence of androgen deficiency syndrome in men varies depending on the age group, known and unknown comorbidities, and the respective study group. Reported prevalence rates may be underestimated, as not every man with symptoms of androgen deficiency seeks treatment. Additionally, men reporting symptoms of androgen deficiency may not be correctly diagnosed due to the vagueness of the symptom quality. The treatment of androgen deficiency syndrome or male hypogonadism may sometimes be difficult due to various reasons. There is no consensus as to when to start treating a respective man or with regards to the best treatment option for an individual patient. There is also lack of familiarity with treatment options among general practitioners. The formulations currently available on the market are generally expensive and dose adjustment protocols for each differ. All these factors add to the complexity of testosterone replacement therapy. In this article we will discuss the general indications of transdermal testosterone replacement therapy, available formulations, dosage, application sites, and recommended titration schedule.
\end{abstract}

Keywords: hypogonadism, transdermal, testosterone, sexual function, testosterone replacement therapy, estradiol

\section{Introduction}

Late onset hypogonadism with androgen deficiency syndrome in men is a frequently diagnosed condition associated with clinical symptoms including fatigue, decreased libido, erectile dysfunction, decreased muscle and lean body mass, low bone mineral density, metabolic syndrome, and depression. ${ }^{1-5}$ Total, free, and bioavailable testosterone and sex hormone binding globulin may all be significantly reduced in men with metabolic syndrome compared to those without metabolic syndrome. ${ }^{5}$

In older men an optimal plasma testosterone level is associated with reduced all-cause mortality, ${ }^{6}$ and serum testosterone concentrations decline steadily with age. Some studies report that the mean total serum testosterone concentration of men at age 75 years is about two thirds of the levels at age 25 years. ${ }^{7}$ Approximately $50 \%$ of men older than 80 years and about $20 \%$ of men older than 60 years have serum testosterone concentrations at least two standard deviations below the mean concentration for young men..$^{8,9}$ The actual prevalence of androgen deficiency syndrome or male hypogonadism in men is not definitely known. When considering symptomatic androgen deficiency as defined by a total serum testosterone concentration below $300 \mathrm{ng} / \mathrm{dL}$ and/or free testosterone concentration below $5 \mathrm{ng} / \mathrm{dL}$ in addition to the presence of low sex drive, erectile 
dysfunction, osteoporosis or fracture, or two or more of the following symptoms including sleep disturbance, depressed mood, lethargy, diminished physical performance, the prevalence of symptomatic androgen deficiency in men between age 30 and 79 years is about $6 \% .^{10}$

Obviously, the definition of male hypogonadism depends not only on clinical symptoms and signs but also on cutoff levels of serum testosterone concentrations. Most authorities would consider as the lower limit of the normal range a serum total testosterone concentration of $315 \mathrm{ng} / \mathrm{dL}$ in healthy nonobese men, and of $6.5 \mathrm{ng} / \mathrm{dL}$ for free testosterone (measured by equilibrium dialysis or absolutely reliable assays). ${ }^{7}$ A consensus statement by the International Society of Andrology, International Society for the Study of Aging Male, European Association of Urology, European Academy of Andrology, and American Society of Andrology, concluded that there are no generally accepted lower limits of normal serum testosterone and that men with a serum concentration above $350 \mathrm{ng} / \mathrm{dL}$ generally do not require substitution therapy, while men with serum testosterone concentrations below $230 \mathrm{ng} / \mathrm{dL}$ will usually benefit from testosterone replacement therapy (TRT). ${ }^{11}$

Of note, there are large inter-individual variations of free testosterone concentrations and it is unclear how a certain cutoff level of total or free serum testosterone can be used to confirm "normalcy". For instance, man A may have had a total testosterone value of $900 \mathrm{ng} / \mathrm{dL}$ at age 20 years and now at age 50 has a value of $400 \mathrm{ng} / \mathrm{dL}$ with symptoms of androgen deficiency syndrome, whereas man B with a total testosterone value of $400 \mathrm{ng} / \mathrm{dL}$ at age 50 years and no symptoms of androgen deficiency syndrome may have had a value of $500 \mathrm{ng} / \mathrm{dL}$ at age 20 years. The normal total serum testosterone range in healthy adult males is said to be between 315 and 1,000 ng/dL based on blood production and metabolic clearance rates. ${ }^{7}$

The prevalence of male hypogonadism may be underestimated, as not every man with symptoms of hypogonadism seeks treatment. Additionally, men reporting symptoms of hypogonadism may not be correctly diagnosed due to the vagueness of the symptoms. Even in patients with a confirmed diagnosis, the treatment course can be difficult due to lack of familiarity with treatment options.

Various therapy choices are available to replace testosterone in men including oral, intramuscular, subcutaneous, and transdermal preparations. ${ }^{12}$ Most men (age 22 to 69 years) prefer a topical gel product over an injection or patch due to its ease of use. ${ }^{13}$ Unfortunately, there is no consensus as to when to treat a patient, or what the best treatment option is for an individual patient. There are many factors that have to be considered in each individual with their unique genetic and environmental makeup which have not been well studied in large scale trials but rather become clear by practice-based evidence (see also The CARE [CAseREport] guidelines: consensus-based clinical case report guideline development). ${ }^{14,15}$

The topical formulations available on the market are generally expensive and dose adjustment protocols for each of them differ. All these factors add to the complexity of TRT for general practitioners. ${ }^{16}$ In this article, we will discuss the general indications of transdermal TRT, available formulations, dosage, application sites, and recommended titration schedule.

\section{Physiology of testosterone}

Testosterone is essential for development and maintenance of various organs and physiological functions in men. It is a steroid hormone which exerts effects on the male throughout life. ${ }^{17,18}$ The male fetus develops the cells of Leydig around the seventh week of development which begin to produce testosterone. Testosterone leads to differentiation of the male fetal genitourinary tract with development of epididymis, seminal vesicles, and vas deferens. The external male genitalia begin to develop at around 8 weeks of fetal life. Testosterone starts to exert its effects on the development of secondary sexual characteristics in males during puberty. The hypothalamus begins to secrete gonadotropin-releasing hormone $(\mathrm{GnRH})$ from the hypothalamus in a pulsatile fashion, with release of both luteinizing hormone ( $\mathrm{LH})$ and follicle-stimulating hormone (FSH) from the anterior pituitary (Figure 1).

LH stimulates the Leydig cells in the testes to produce testosterone, causing development of male secondary sexual characteristics. An elevated serum testosterone concentration causes negative feedback inhibition of the hypothalamicpituitary-gonadal (HPG) axis by decreasing GnRH and LH/ FSH from the hypothalamus and anterior pituitary. In addition to development of secondary sexual characteristics in males, testosterone also has various physiological effects in the body including maintaining lean muscle and bone mass, spermatogenesis, libido, improving insulin sensitivity, and glucose metabolism, etc.

After secretion by the testes, about $97 \%$ of testosterone becomes either loosely bound with plasma albumin or more tightly bound with a beta globulin called sex hormonebinding globulin (SHBG). The rest circulates in the blood in free/unbound form. ${ }^{19}$ The circulating testosterone is either transferred to the tissues or degraded into inactive products that are subsequently excreted. Factors that increase SHBG, 


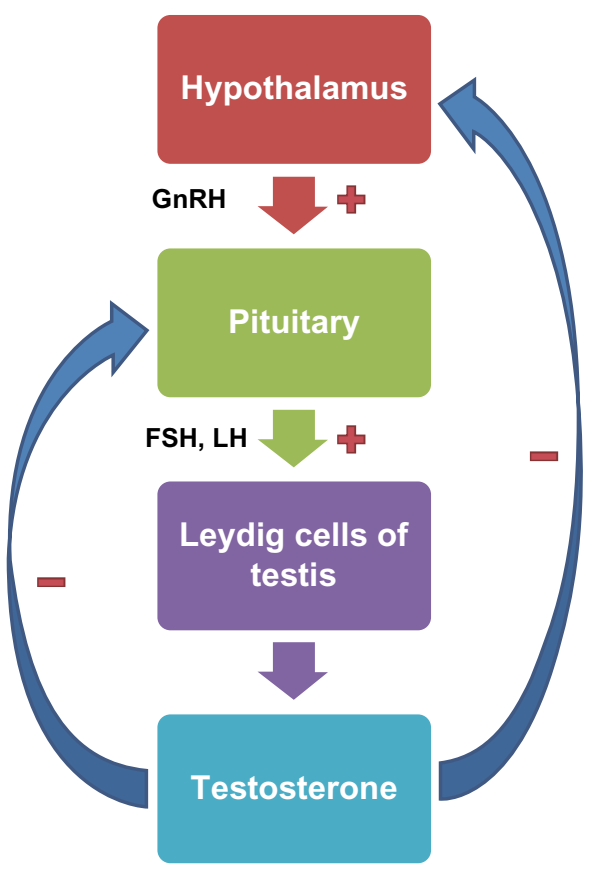

Figure I Hypothalamic-pituitary-gonadal axis and testosterone secretion. Abbreviations: $\mathrm{FSH}$, follicle-stimulating hormone; $\mathrm{GnRH}$, gonadotropin-releasing hormone; LH, luteinizing hormone.

like hyperthyroidism, cirrhosis of the liver, aging, and others decrease the amount of bioavailable testosterone in the circulation. Much of the testosterone that becomes fixed to the tissues is converted within the tissue cells to dihydrotestosterone by the enzyme $5 \alpha$-reductase, especially in certain target organs such as the prostate gland in the adult and the external genitalia of the male fetus. Some actions of testosterone are dependent on this conversion, whereas other actions are not. Testosterone that does not become fixed to the tissues is rapidly converted, mainly by the liver, into androsterone and dehydroepiandrosterone and simultaneously conjugated as either glucuronides or sulfates. These are excreted from the body through bile or urine.

Of note, estrogen-mediated actions of testosterone in men include feedback regulation of $\mathrm{LH}$, skeletal homeostasis, lipid metabolism, and others. ${ }^{7,20-26}$ Estrogenic actions in men can occur through blood borne estrogens and through local aromatization of testosterone.

Approximately $0.3 \%$ of testosterone is converted into estradiol by aromatase (CYP19A1), an enzyme expressed in the brain, liver, and adipose tissues. ${ }^{27}$ In obese men, the increased amount of fat leads to increased extragonadal aromatase activity, resulting in increased concentrations of estradiol. High circulating concentrations of estradiol down regulate the HPG axis and decrease the amount of circulating testosterone. Up to $80 \%$ of plasma estradiol originates from aromatization of testosterone and less than $20 \%$ of estradiol in the circulation is secreted by the testes. Serum estradiol concentrations in men are around 20 to $30 \mathrm{pg} / \mathrm{mL}$ and do not vary significantly with age with some elderly men having higher estradiol serum concentrations than postmenopausal women. ${ }^{7,28}$ In aging men, both estrogen and testosterone are important in maintaining bone formation. ${ }^{21}$ Estrogens also play a role in energy balance and glucose homeostasis. ${ }^{29}$

\section{Diagnosis of male hypogonadism}

The symptoms of male hypogonadism may be nonspecific and often mimic many other diseases, making the diagnosis difficult. As a general rule, any chronic (inflammatory) condition that puts one out of eustasis may lead to "sick gonadotroph syndrome" (Figure 2). ${ }^{30}$ In this context, chronic pain and/or chronic opioid use can cause hypogonadism which can be successfully treated by testosterone gel. ${ }^{31}$ Patients can generally present with unexplained fatigue, depression, loss of libido, or erectile dysfunction (Table 1). After exclusion of other diseases, hypogonadism should be suspected and appropriate tests should be ordered to establish the diagnosis (Figure 2 based on Wang et al ${ }^{11}$ regarding serum testosterone cutoff concentrations).

The challenge arises when a reference range for normal serum testosterone is sought for the elderly male population since an individual's testosterone concentration constantly declines naturally over the later decades of life. A recent study proposed that the 2.5 th percentile $(184 \mathrm{ng} / \mathrm{dL}$ of serum total testosterone) in a reference group of healthy elderly men may provide age appropriate thresholds for defining the cutoff point for low testosterone..$^{32}$ Of note, more than $80 \%$ of circulating estradiol in men comes from the conversion/ aromatization of testosterone. ${ }^{33}$ Estrogen deficiency may primarily account for increases in body fat.$^{34}$ Apparently, men with a testosterone level below $200 \mathrm{ng} / \mathrm{dL}$ start to experience loss of lean mass and muscle strength, acknowledging, however, that sensitivity of various androgen target tissues varies, ie, this level of $200 \mathrm{ng} / \mathrm{dL}$ is not an absolute number. ${ }^{34,35}$

After diagnosing hypogonadism, the currently available treatment options should be considered and discussed with the patient. The oral formulations containing 17- $\alpha$-testosterone are no longer used due to their potential liver toxicity because of the hepatic first pass metabolism, while there is no published evidence that indicates nonoral formulations causing liver toxicity. Buccal formulations have the convenience of oral administration with low potential for hepatotoxicity as they bypass the hepatic first pass metabolism, but have a 


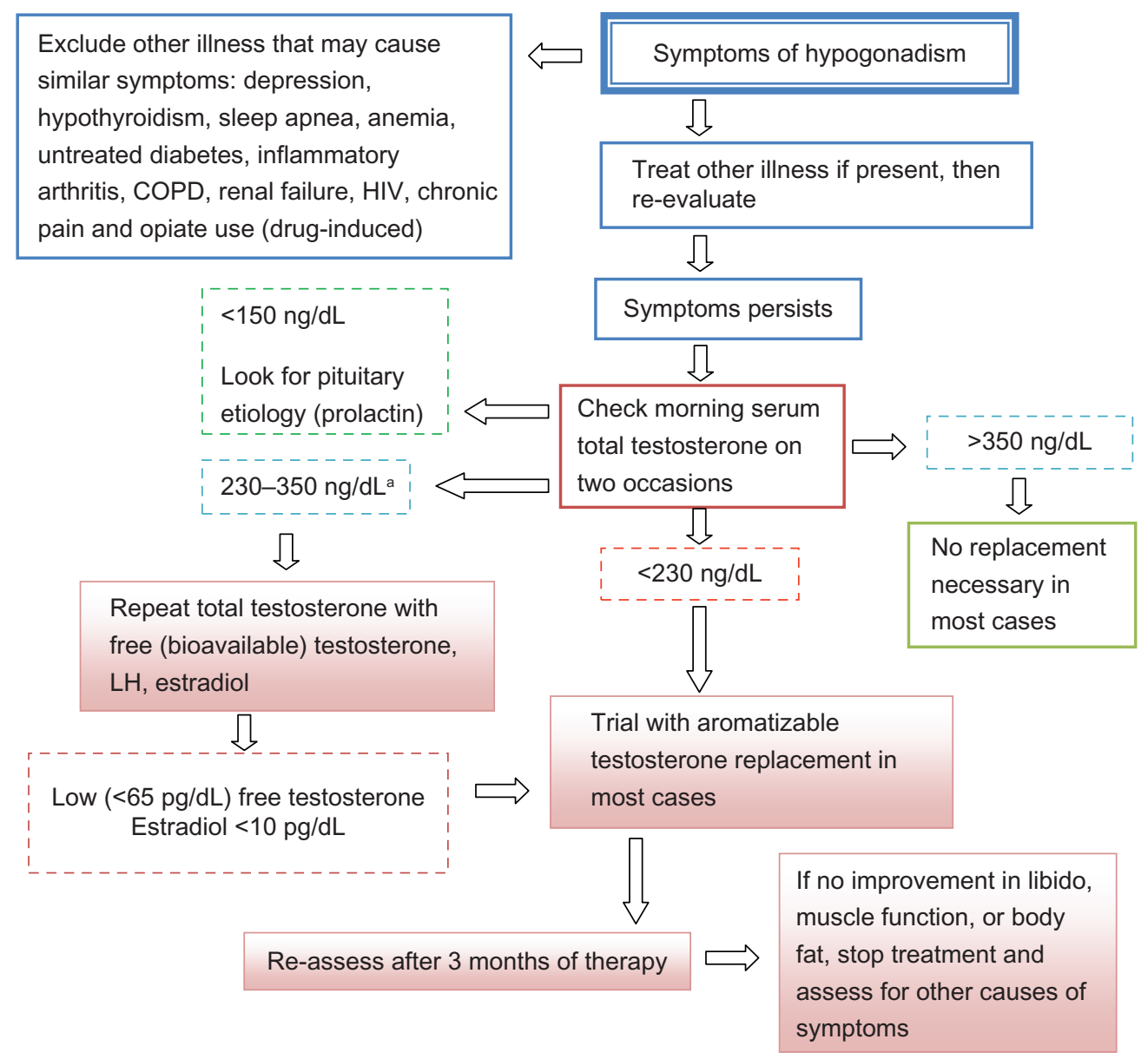

Figure 2 Algorithm for diagnosis and treatment of male hypogonadism.

Notes: alf significant symptoms exist, may consider treatment regardless of additional laboratory results. Adapted with permission from Thieme. Ullah MI, Washington T, Kazi M, Tamanna S, Koch CA. Testosterone deficiency as a risk factor for cardiovascular disease. Horm Metab Res. 20II;43(3): I53-164.41 Copyright @ 20II.

Abbreviations: COPD, chronic obstructive pulmonary disorder; HIV, human immunodeficiency virus; LH, luteinizing hormone.

short duration of action requiring 2-3 times daily dosing, mouth-related adverse effects (gum and mouth pain, gum edema, bitter taste, taste perversion), ${ }^{36}$ and the clinical response is less consistent. Intramuscular depot injection of testosterone cypionate is less expensive and can be administered every 1-4 weeks. A major disadvantage is the strongly fluctuating concentrations of plasma testosterone

Table I Symptoms and signs of testosterone deficiency

\begin{tabular}{ll}
\hline Typical symptoms and signs & $\begin{array}{l}\text { Nonspecific symptoms } \\
\text { and signs }\end{array}$ \\
\hline Reduced libido, erectile dysfunction & Generalized fatigue \\
Decreased spontaneous (morning) & $\begin{array}{l}\text { Reduced muscle bulk and strength } \\
\text { erections }\end{array}$ \\
Loss of body (axillary and pubic) hair & Poor concentration and memory \\
Small (especially $<5 \mathrm{~mL}$ ) or shrinking & Sleep disturbance, increased \\
testes & sleepiness \\
Infertility, low sperm count & Mild anemia (iron deficiency) \\
Pathological fracture, low bone & Increased body fat and metabolic \\
mineral density & syndrome \\
\hline
\end{tabular}

Notes: Data from Ullah et al, and Koch and Zitzmann. 41,42,58 which are at least $50 \%$ of the time not in the physiological range. ${ }^{37}$ This also causes supraphysiologic serum testosterone concentrations within 2 to 3 days of injection and a slow decline to subnormal levels within 1 to 2 weeks. This noncircadian type of roller coaster pharmacokinetic response may cause rapid swings in energy, mood, and sexual function. ${ }^{38}$ Application regimens of $200 \mathrm{mg}$ every 2 weeks and $300 \mathrm{mg}$ every 3 weeks seem to be effective in moving serum LH concentrations into the normal range. ${ }^{39}$ Implantable testosterone pellets are also available but require surgical intervention, may be painful, and are sometimes extruded spontaneously from the implant site. Convenience appears to be the most important factor in patients' decision to choose subcutaneous pellets therapy, but the cost of therapy is the primary reason for discontinuing it. ${ }^{40}$ Besides intramuscular testosterone injection, transdermal TRT (gel and patch) are the most common formulations used in the US to treat hypogonadism. We will discuss the dosage and application procedures of the commonly available transdermal 
Table 2 Recent articles on advances in testosterone replacement therapy

\begin{tabular}{|c|c|c|}
\hline Title & Author/Year & Summary of article \\
\hline New modalities of transdermal testosterone replacement ${ }^{43}$ & $\begin{array}{l}\text { Basaria and Dobs, } \\
2003\end{array}$ & $\begin{array}{l}\text { Discusses advantages of transdermal testosterone } \\
\text { formulations compared to other formulations }\end{array}$ \\
\hline Androgen replacement therapy: present and future ${ }^{44}$ & $\begin{array}{l}\text { Gooren and Bunck, } \\
2004\end{array}$ & $\begin{array}{l}\text { Compares buccal, subcutaneous, intramuscular, and } \\
\text { transdermal formulations of testosterone }\end{array}$ \\
\hline Androgens and the ageing male ${ }^{45}$ & $\begin{array}{l}\text { Swerdloff and Wang, } \\
2004\end{array}$ & $\begin{array}{l}\text { Summarizes symptoms of hypogonadism in aging males and } \\
\text { risk/benefit of replacement }\end{array}$ \\
\hline $\begin{array}{l}\text { Testim I\% testosterone gel for the treatment of male } \\
\text { hypogonadism }{ }^{46}\end{array}$ & Bouloux, 2005 & $\begin{array}{l}\text { Reviews the pharmacokinetic and clinical profile of Testim } \\
\text { I\% gel formulation of testosterone for the treatment of } \\
\text { male hypogonadism }\end{array}$ \\
\hline $\begin{array}{l}\text { Recent trends in the treatment of testosterone deficiency } \\
\text { syndrome }{ }^{47}\end{array}$ & Hong and Ahn, 2007 & $\begin{array}{l}\text { Discusses advantages of transdermal testosterone and } \\
\text { experimental use of DHE and HCG to treat hypogonadism }\end{array}$ \\
\hline Testosterone replacement therapy ${ }^{48}$ & Jones, 2007 & $\begin{array}{l}\text { Reviews the physiology, causes, and diagnosis of } \\
\text { hypogonadism and the potential benefits of treatment with } \\
\text { testosterone replacement therapy }\end{array}$ \\
\hline Advances in testosterone replacement therapy ${ }^{37}$ & Gooren, 2009 & $\begin{array}{l}\text { Discusses the different formulations of testosterone } \\
\text { replacement therapies along with advantages of the newer } \\
\text { formulations }\end{array}$ \\
\hline Testosterone treatment in elderly men ${ }^{49}$ & $\begin{array}{l}\text { Srinivas-Sankar and } \\
\text { Sharma, } 2009\end{array}$ & $\begin{array}{l}\text { Discusses the indications, contraindications, and benefits } \\
\text { of testosterone treatment along with adverse effects, } \\
\text { advantages, and disadvantages of various testosterone } \\
\text { preparations }\end{array}$ \\
\hline Update in testosterone therapy for men $^{50}$ & Corona et al, 20II & $\begin{array}{l}\text { Reviews the meta-analytic studies }(1969-2010) \text { and } \\
\text { discusses the pathogenesis of male hypogonadism and the } \\
\text { preparations for its treatment }\end{array}$ \\
\hline $\begin{array}{l}\text { Evidence-based medicine update on testosterone } \\
\text { replacement therapy in male hypogonadism: focus } \\
\text { on new formulations }{ }^{51}\end{array}$ & Giagulli et al, 201 I & $\begin{array}{l}\text { Summarizes important evidences regarding testosterone } \\
\text { replacement therapies, highlighting those concerning } \\
\text { both transdermal and long acting injectable testosterone } \\
\text { compounds }\end{array}$ \\
\hline $\begin{array}{l}\text { Topical testosterone supplementation for the treatment } \\
\text { of male hypogonadism } 52\end{array}$ & $\begin{array}{l}\text { Abadilla and Dobs, } \\
2012\end{array}$ & $\begin{array}{l}\text { Summarizes the indications, contraindications, risk/benefits } \\
\text { of transdermal testosterone replacement therapy }\end{array}$ \\
\hline $\begin{array}{l}\text { The long-term efficacy and safety of a testosterone } \\
\text { mucoadhesive buccal tablet in testosterone-deficient men }{ }^{53}\end{array}$ & $\begin{array}{l}\text { Dinsmore and Wyllie, } \\
2012\end{array}$ & Discusses the new buccal formulation (Striant) \\
\hline $\begin{array}{l}\text { Skin hypersensitivity reactions to transdermal therapeutic } \\
\text { systems - still an important clinical problem }\end{array}$ & Jenerowicz et al, 2012 & $\begin{array}{l}\text { Discusses the cutaneous reactions caused by transdermal } \\
\mathrm{T} \text { preparations and how to prevent/manage it }\end{array}$ \\
\hline
\end{tabular}
Abbreviations: DHE, dehydroepiandrosterone; HCG, human chorionic gonadotropin.

testosterone formulations in the US. We have also compiled a table (Table 2) which summarizes some important journal articles on recent advances in TRT.

\section{Transdermal drug delivery system}

This is a method of drug administration which allows application of a discrete dose of the drug by applying it on the intact skin, which is absorbed at a controlled rate into the systemic circulation..$^{55}$ The skin serves as a reservoir for the sustained release of testosterone into the systemic circulation. It is used for many medications and has the advantage of high bioavailability, absence of hepatic first pass metabolism, increased therapeutic efficacy, and steadiness of plasma concentrations of the drug. For testosterone replacement, two subtypes of transdermal application systems are available in the US. One is in the form of a patch containing testosterone that is applied to the skin daily. Androderm (Actavis, Inc.,
Dublin, Ireland) is the only testosterone patch available in the US. Testoderm (Actavis, Inc.) is another testosterone patch (applied on scrotal skin) which is not available in the US. The others are in the form of gels containing testosterone which is applied directly on the skin. Several gel formulations are available in the US and doses and application sites for each medication vary, increasing the difficulty in prescribing and monitoring the treatment response for the provider. In the next few sections, we will try to summarize the similarities and differences of each medication. Of note, a study from 1989 utilizing testosterone transdermally containing 5,10 , or $15 \mathrm{mg}$ of testosterone showed that peak concentrations of testosterone were achieved 3 to 8 hours after scrotal application in hypogonadal men. ${ }^{56}$ In that study, a potential disadvantage has become apparent as there was a disproportionate increase in serum dihydrotestosterone, likely because skin highly expresses 5-alpha reductase. 


\section{Transdermal patch}

Androderm ${ }^{\circledR}$ is a transdermal testosterone patch available in the US and some other countries but not in the UK. It is supplied in $2 \mathrm{mg} /$ day and $4 \mathrm{mg} /$ day dose forms. The other testosterone patch called Testoderm is no longer available on the market. It is recommended to start with the application of one $4 \mathrm{mg} /$ day uncut/torn Androderm patch nightly on the clean, dry, and unbroken skin on the back, abdomen, upper arms, or thighs only. It should not be applied to skin on the scrotum, buttocks, or any bony area. The sites of application should be rotated weekly and should not be used more frequently than every 7 days. This may reduce the risk for skin irritation. More than one patch applied simultaneously may be required to reach adequate serum testosterone concentrations. The patient should avoid showering, swimming, or washing the site for at least 3 hours after application to allow adequate absorption of the drug into the subcutaneous tissue where it remains stored for continuous release into the systemic circulation. Minor skin irritation (occurs in up to $30 \%$ of men) may be treated by applying over the counter hydrocortisone cream on the affected skin after removal of the patch. If a patch is dislodged from the skin prior to noon, a new patch can replace it; if the patch is dislodged later in the day, the patient should wait until the next scheduled application. For dose titration, an early morning total serum testosterone should be checked at least 2 weeks after initiation of therapy, following system application the previous evening. The target range of serum testosterone is between 400 and $930 \mathrm{ng} / \mathrm{dL}$.

\section{Transdermal gels}

Several testosterone gel formulations are available for topical use in the US. These include Androgel ${ }^{\circledR}$ (1\% and 1.62\%) (AbbVie Inc., Lake Bluff, IL, USA), Axiron ${ }^{\circledR}$ (Eli Lilly and Company, Indianapolis, IN, USA), Fortesta ${ }^{\circledR}$ (Endo Pharmaceuticals Inc., Malvern, PA, USA), and Testim ${ }^{\circledR}$ (Auxilium Pharmaceuticals Inc., Chesterbrook, PA, USA). Their indications, adverse effects, and contraindications are fairly similar, but the dose adjustments and application sites differ significantly and are not interchangeable (Table 3). In general, the patients should wash hands immediately with soap and water after applying the gel and cover the application site with clothing after the gel has dried. They should also wash the application site thoroughly with soap and water, if skin to skin contact of the application site with another person is anticipated. The dose should be titrated based on the (total) serum testosterone concentration checked at least 2-4 weeks after therapy initiation or after any dose adjustment. In a study with healthy young men, $150 \mathrm{mg}$ of topical testosterone gel administration resulted in maximum total serum testosterone concentrations 3 hours after administration without suppressing $\mathrm{LH} .{ }^{57}$ Serum testosterone concentrations can generally be assessed any time after the individual man has been on treatment for at least 1 week..$^{58}$ Kinetics data of different transdermal testosterone formulations are presented in Table 4. Interestingly, a recent study of healthy young men who received $150 \mathrm{mg}$ of testosterone in topical gel showed a maximum total serum testosterone concentration 3 hours after administration without suppression of $\mathrm{LH}$ at any time point over 1 hour intervals for 7 hours after gel administration. ${ }^{57}$ Administration of $2 \mathrm{mg}$ estradiol in topical gel led to maximum estradiol serum concentration 2 hours after administration and did not suppress absolute LH concentrations. ${ }^{57}$

Androge $\mathrm{l}^{\circledR}$ : This medication comes in two different formulations, $1 \%$ and $1.62 \%$. Both are applied to the clean and dry intact skin of the shoulder or upper arm once daily in the morning. The dosage and administration of each differs from the others. Each comes in a pump and in a packet. The starting dose of Androgel 1\% is $50 \mathrm{mg}$ of testosterone (four pump actuation, two $25 \mathrm{mg}$ packets or one $50 \mathrm{mg}$ packet). On the other hand, Androgel 1.62\% should be started at $40.5 \mathrm{mg}$ (two pump actuation, $20.25 \mathrm{mg}$ each or one $40.5 \mathrm{mg}$ packet). The dose should be titrated based on the predose morning serum concentration of (total) testosterone checked after at least 2-4 weeks of therapy initiation or after any dose adjustment. The $1.62 \%$ formulation is more concentrated which allows

Table 3 Comparison of different transdermal testosterone formulations

\begin{tabular}{|c|c|c|c|c|}
\hline Medication & $\begin{array}{l}\text { Application } \\
\text { site }\end{array}$ & Formulation & Starting dose & $\begin{array}{l}\text { Time of blood draw to } \\
\text { recheck concentration }\end{array}$ \\
\hline Androgel I\% & $\begin{array}{l}\text { Shoulder or } \\
\text { upper arm }\end{array}$ & $\begin{array}{l}\text { I pump }=12.5 \mathrm{mg} \\
\text { I packet }=25 \mathrm{mg}, 50 \mathrm{mg} \text { of testosterone }\end{array}$ & $\begin{array}{l}\text { Four pump actuation, two } 25 \mathrm{mg} \\
\text { packets or one } 50 \mathrm{mg} \text { packet }\end{array}$ & Early morning \\
\hline Androgel $1.62 \%$ & $\begin{array}{l}\text { Shoulder or } \\
\text { upper arm }\end{array}$ & $\begin{array}{l}\text { I pump }=20.25 \mathrm{mg} \\
\text { I packet }=40.5 \mathrm{mg} \text { of testosterone }\end{array}$ & $\begin{array}{l}\text { Two pump actuation or one } \\
40.5 \mathrm{mg} \text { packet }\end{array}$ & Early morning \\
\hline Axiron & Axilla & I pump $=30 \mathrm{mg}$ of testosterone & Two pump actuation & After 2-8 hours of application \\
\hline Fortesta & Thigh & I pump $=10 \mathrm{mg}$ of testosterone & Four pump actuation & After 2 hours of application \\
\hline Testim I\% & $\begin{array}{l}\text { Shoulder or } \\
\text { upper arm }\end{array}$ & $\begin{array}{l}\text { I tube }=50 \mathrm{mg} \text { of testosterone } \\
\text { in } 5 \mathrm{~g} \text { of gel }\end{array}$ & I tube & Early morning \\
\hline
\end{tabular}


Table 4 Kinetics and composition of different transdermal testosterone formulations ${ }^{\mathrm{a}-\mathrm{c}}$

\begin{tabular}{|c|c|c|c|}
\hline Medication & Absorption & Duration & Inactive ingredients \\
\hline Androgel I\% & $\begin{array}{l}\text { Continuous - } \\
10 \% \text { bioavailable }\end{array}$ & $\begin{array}{l}5 \text { days after achieving } \\
\text { steady state }\end{array}$ & $\begin{array}{l}\text { Carbomer } 980 \text {, ethyl alcohol } 67.0 \% \text {, isopropyl myristate, } \\
\text { sodium hydroxide, purified water }\end{array}$ \\
\hline Androgel $1.62 \%$ & Continuous & $48-72$ hours & $\begin{array}{l}\text { Carbopol 980, ethyl alcohol, isopropyl myristate, } \\
\text { sodium hydroxide, purified water }\end{array}$ \\
\hline Axiron & $\begin{array}{l}\text { Reservoir of testosterone } \\
\text { and octisalate }\end{array}$ & $\begin{array}{l}7-10 \text { days after } \\
\text { reaching steady state }\end{array}$ & Ethanol, isopropyl alcohol, octisalate, and povidone \\
\hline Fortesta & Continuous & $24-48$ hours $^{\text {d }}$ & $\begin{array}{l}\text { Propylene glycol, purified water, ethanol, 2-propanol, oleic acid, } \\
\text { carbomer } 1382 \text {, triethanolamine, and butylated hydroxytoluene }\end{array}$ \\
\hline Testim I\% & $\begin{array}{l}\text { Sustained release - } \\
10 \% \text { bioavailable }\end{array}$ & $24-48$ hours $^{d}$ & $\begin{array}{l}\text { Pentadecalactone, carbopol, acrylates, propylene glycol, glycerin, } \\
\text { polyethylene glycol, ethanol ( } 74 \%) \text {, tromethamine, purified water }\end{array}$ \\
\hline
\end{tabular}

less gel to be applied and improves skin permeation compared to the $1 \%$ gel.

Axiron $2{ }^{\circledR}$ : This is the only formulation that has received US Food and Drug Administration (FDA) approval for application under arms (axilla). It is an odorless formulation that comes in a metered dose pump with a silicone applicator. The starting dose is one pump actuation $(30 \mathrm{mg}$ ) to be applied in each axilla (total $60 \mathrm{mg} /$ day) every morning. The dose should be titrated based on the serum concentration of testosterone after 2-8 hours of application, checked after at least 2 weeks of therapy initiation or after any dose adjustment. It has minimal local adverse reactions including skin erythema and edema. Its efficacy is not compromised by concomitant use of deodorant or antiperspirant but it is recommended to apply deodorant prior to application of Axiron to avoid contamination of deodorant sticks. ${ }^{59}$

Fortesta $2 \%^{\circledR}$ : This is a clear, odorless gel which is low in volume and is one of the least expensive transdermal formulations available. ${ }^{60}$ This formulation comes in only pump dispensing format. It is started at $40 \mathrm{mg}$ of testosterone daily (four pump actuation) applied every morning on the dry, intact skin of the front or inner thighs. The dose should be titrated based on the serum concentration of testosterone after a single blood draw after 2 hours of application, checked after at least 2 weeks of therapy initiation or after any dose adjustment. This formulation has been reported to restore testosterone concentrations in $77 \%$ of men in a study, without risk of supra-physiologic testosterone concentrations. ${ }^{61}$

Testim $1 \%{ }^{\circledR}$ : This is a translucent gel formulation with slightly musky odor that has variable patient acceptability. The formulation contains an emollient which helps reduce drying out of the skin and enables higher testosterone absorption. ${ }^{62,63}$ The drug is provided in $5 \mathrm{~g}$ tubes, each containing $50 \mathrm{mg}$ of testosterone. The recommended starting dose is $5 \mathrm{~g}$ of gel (one tube) containing $50 \mathrm{mg}$ of testosterone to be applied once daily in the morning to clean, dry intact skin of the shoulders or upper arms. Morning serum testosterone concentrations should be measured approximately 2 weeks after initiation of therapy to ensure that proper serum testosterone concentrations are achieved. Reportedly, Testim $1 \%$ produces higher serum concentrations and greater bioavailability than Androgel 1\% with $\mathrm{C}_{(\max )}$ estimates for total testosterone, dihydrotestosterone, and free testosterone being greater $(30 \%, 19 \%$, and $38 \%$, respectively) following the application of Testim compared to AndroGel. ${ }^{63}$

\section{Potential adverse effects of testosterone replacement}

- Worsening symptoms of benign prostatic hyperplasia (likely preventable or being averted with co-administration of finasteride $)^{64}$

- Virilization in females or children with accidental exposure

- Polycythemia ${ }^{65,66}$

- Edema

- Gynecomastia

- Dyslipidemia

- Hypercalcemia

- Application site reaction

- Increased risk of prostate cancer ${ }^{66,67}$ (unproven)

- Emotional lability (putative)

- Hypertension (putative)

- Alopecia

- Priapism $^{68,69}$ (unlikely).

\section{Contraindications to testosterone therapy}

- History of breast or prostate cancer ${ }^{41,58}$

- Presence of palpable prostate nodule or induration ${ }^{41,58}$ 
- Prostate-specific antigen (PSA) $>4 \mathrm{ng} / \mathrm{mL}$ or $>3 \mathrm{ng} / \mathrm{mL}$ in men at high risk for prostate cancer such as AfricanAmericans, or men with first degree relatives with prostate cancer, without further urological evaluation ${ }^{41,58}$

- Untreated severe obstructive sleep apnea ${ }^{41,58}$

- Uncontrolled or poorly controlled heart failure ${ }^{41,58}$

- Severe lower urinary tract symptoms with International Prostate Symptom Score above 19 (symptoms unchanged or even improved $)^{70,71}$

- Hematocrit $>50 \%{ }^{41,58}$

\section{Disadvantages of transdermal TRT}

The transdermal formulations available for TRT are generally expensive. Some patients may develop mild skin irritation while others may develop more serious skin reactions. Those who sweat excessively may have difficulty wearing the patch. Transference is a major concern and has been the topic of FDA warnings. ${ }^{72}$ Accidental transference can lead to virilization of contacts, especially in children. ${ }^{73}$ To prevent it, areas of application should be covered with clothing as soon as the gel has dried. Hands should be thoroughly washed with soap and water after application. If skin to skin contact is anticipated, the area should be washed thoroughly before contact. Swimming and bathing should be avoided for at least 2 hours after application. Special care must also be taken to avoid any contact possibility with pregnant women, as there is potential for teratogenicity.

\section{Monitoring ofTRT}

Patients treated with testosterone replacement should be monitored for both treatment response as well adverse effects. They should be clinically evaluated and their serum testosterone concentrations should be checked 2-3 months after initiation of therapy and after adjusting the dose. The target serum testosterone concentration to be achieved for injectable testosterone enanthate or cypionate is said to be around 400-700 ng/dL which has been considered to be eugonadal by the Endocrine Society clinical practice guideline (2010) ${ }^{58,74}$ For other testosterone formulations, no specific range is given other than "mid-normal," presumably also 400-700 ng/dL. Obviously, as stated before, there are large inter-individual variations and the serum testosterone concentration should therefore be seen in the context of signs and symptoms of each individual man. Higher (up to $1,000 \mathrm{ng} / \mathrm{dL}$ ) and lower (as low as $300 \mathrm{ng} / \mathrm{dL}$ ) concentrations may be considered acceptable responses to treatment. Some panelists of the Endocrine Society clinical practice guideline favored treating symptomatic older men who had serum testosterone concentrations below the lower limit of normal healthy young men $(300 \mathrm{ng} / \mathrm{dL})$, while others were in favor of not treating unless the testosterone concentration is below $200 \mathrm{ng} / \mathrm{dL} .{ }^{58}$ The timing of serum concentration measurement varies slightly depending on the preparation used, which has been summarized in Tables 3 and 4. Whereas the recommendation for injectable testosterone esters is to check the serum concentration midway between injections, it is recommended for serum testosterone to be evaluated 3 to 12 hours after application of the transdermal patch, to assess serum testosterone immediately before or after application of fresh system of buccal testosterone, to measure serum testosterone any time after the patient has been on treatment with gel for at least 1 week, and to evaluate serum testosterone at the end of the dosing interval for testosterone pellets, all with the aim to achieve "mid-normal" range of serum testosterone concentrations.

Monitoring for adverse effects from TRT should also be done. A PSA concentration, digital rectal examination, and hematocrit should be performed at baseline and at 3 months, 6 months, then yearly after TRT is initiated. If the hematocrit rises above $54 \%$, treatment should be discontinued until resolution to a safe level..$^{58}$ We feel such a hematocrit level should be $45 \%$ and then testosterone therapy can be reinitiated at reduced dose compared to the prior dose.$^{58}$ Consider discontinuation of TRT and/or referral to a urologist if PSA measurements increase in consecutive 6-month intervals, or an increase of serum PSA $>1.4 \mathrm{ng} / \mathrm{mL}$ in a year. ${ }^{58}$ If the digital rectal examination is abnormal, a biopsy should be performed to rule out prostate cancer. Additionally, a voiding assessment and breast examination should be performed at baseline and annually as long as TRT is continued. In men with osteoporosis or a history of low trauma fracture, bone mineral density of the lumbar spine should be measured after 1 to 2 years of continued TRT.

\section{Timeline of response to therapy after testosterone replacement}

The clinical response to transdermal testosterone supplement is variable. Generally, it takes $4-12$ weeks to restore the serum testosterone concentration to physiological range, depending on the initial concentration of the hormone as well as the type of formulation used. Serum testosterone is usually measured to monitor response to therapy and achievement of a eugonadal state (generally considered to be reflected by a serum testosterone concentration between 400 and $700 \mathrm{ng}) .{ }^{58}$ However, a recent study has suggested 
that it may sometimes be inaccurate because of abnormal fluctuation of other circulating androgens. ${ }^{75}$ Improvement in sexual desire and function as well as mood and energy occurs early in the course of treatment, approximately within 3-6 weeks. $^{76-78}$

One can begin to see improved muscle mass and strength, reduced adiposity, and an increasing hematocrit within 3 months which reaches its maximum at around 12 months. ${ }^{77}$ The lipid profile begins to improve in 3-4 months, with maximum effect attained in 12 months for total cholesterol and 22 months for triglyceride, high density lipoprotein, and low density lipoprotein. A decline in fasting blood glucose and $\mathrm{HbA}_{1 \mathrm{c}}$ may be observed after 3 months with further decrease after 12 months. ${ }^{79-82}$ Effects of testosterone on bone mineral density take longer to appear. It may take 6 months to see the initial effect and may take 36 months or longer to reach the maximum benefit. ${ }^{26,64,83,84}$ Patients with metabolic syndrome experience maximum benefit in waist circumference, fasting blood glucose, and blood pressure within 12 months. $^{79,85}$ It is important to monitor blood glucose concentrations in diabetic patients and titrate down anti-diabetic medications if necessary, as TRT improves glycemic control and may precipitate hypoglycemia.

As per the Endocrine Society clinical practice guideline, men should be monitored for a clinical response and any adverse effects as well as for serum testosterone concentrations, hematocrit, and PSA every 3 months. ${ }^{58}$ Testosterone therapy can inhibit hepcidin transcription and is associated with increased iron incorporation into red blood cells and increased erythropoietin concentrations. ${ }^{86}$ If the hematocrit rises above 54\%, it has been recommended to hold TRT until the hematocrit decreases to a "safe" level (for instance, to less than $45 \%$ to lower the risk of cardiovascular death and major thrombosis). ${ }^{87,88}$ If the hematocrit rises above $45 \%$, whole blood viscosity increases above normal. ${ }^{89}$ Therefore, we would wait until the hematocrit drops to $45 \%$ and then reinitiate testosterone therapy at reduced dose.

A recent study of medical claims analysis has revealed that adherence to the topical TRT among hypogonadal patients is fairly low. ${ }^{90}$ Only $34 \%$ of patients continued with treatment after 6 months of therapy and only $15 \%$ continued after 1 year. ${ }^{90}$ Adherence to both Testim and Androgel were similar in this study. It is not clear what contributes to this low adherence to TRT. Several factors may be accountable. Cost of medication always is a major factor in adherence to any therapy. Those who have no prescription coverage or who have high copay may be less likely to continue topical testosterone. Some patients may also have unrealistic expectations from the therapy. As it may take up to 3 months to demonstrate a clinical response, some men may be reluctant to continue over a longer duration. The physicians must discuss the goals of therapy and encourage patients to not discontinue TRT without consulting the prescribing provider. If a patient does not achieve minimal biochemical goals (ie, serum testosterone $>400 \mathrm{ng} / \mathrm{dL}$ ) with a certain formulation after 3 months, or does not experience symptomatic improvement despite biochemical replacement, it is reasonable to switch to a different transdermal formulation. A study by Grober et al found that hypogonadal symptoms improved in a significant proportion of men who underwent a brand substitution (from Androgel to Testim and vice versa) after an initial suboptimal biochemical or symptomatic response with either product. ${ }^{91}$ If transdermal treatment does not achieve the goal, or cost becomes an obstacle, use of intramuscular testosterone enanthate or cypionate may always remain as a reasonable alternative therapy.

\section{Conclusion}

Transdermal TRT can replace testosterone in men with hypogonadism and restore a steady testosterone concentration in the blood. Transdermal TRT has a more favorable adverse effect profile when compared to buccal testosterone formulations. It also has better patient acceptance when compared to injectable testosterone forms. Different formulations available in the US have different recommended dosages and application sites. Familiarity with each testosterone formulation is needed for the prescribing providers to appropriately administer and monitor efficacy of transdermal TRT. The patients should also be instructed properly to exercise caution to minimize adverse effects and accidental transference.

\section{Disclosure}

The authors report no conflicts of interest in this work.

\section{Resources}

1. Bhasin S, Cuningham GR, Hayes FJ, et al. Testosterone therapy in adult men with androgen deficiency syndromes: an Endocrine Society Clinical Practice Guideline. Available from: https://www.endocrine.org/ /media/ endosociety/Files/Publications/Clinical\%20Practice $\% 20$ Guidelines/FINAL-Androgens-in-Men-Standalone.pdf. Accessed November 10, 2013.

2. Virtual Library. International Society of Andrology. Available from: http://www.andrology.org/library. Accessed December 5, 2013. 


\section{References}

1. Rao PM, Kelly DM, Jones TH. Testosterone and insulin resistance in the metabolic syndrome and T2DM in men. Nat Rev Endocrinol. 2013;9(8):479-493.

2. Kelly DM, Jones TH. Testosterone: a vascular hormone in health and disease. J Endocrinol. 2013;217(3):R47-R71.

3. Giannoulis MG, Martin FC, Nair KS, Umpleby AM, Sonksen P. Hormone replacement therapy and physical function in healthy older men. Time to talk hormones? Endocr Rev. 2012;33(3):314-377.

4. Shi Z, Araujo AB, Martin S, O'Loughlin P, Wittert G. Longitudinal changes in testosterone over five years in community-dwelling men. $J$ Clin Endocrinol Metab. 2013;98(8):3289-3297.

5. Chin K-Y, Ima-Nirwana S, Mohamed IN, Aminuddin A, Ngah WZW. Total testosterone and sex hormone-binding globulin are significantly associated with metabolic syndrome in middle-aged and elderly men. Exp Clin Endocrinol Diabetes. 2013;121(7):407-412.

6. Yeap BB, Alfonso H, Chubb SA, et al. In older men an optimal plasma testosterone is associated with reduced all-cause mortality and higher dihydrotestosterone with reduced ischemic heart disease mortality, while estradiol levels do not predict mortality. J Clin Endocrinol Metab. 2013 Nov 20. [Epub ahead of print].

7. Kaufman JM, Vermeulen A. The decline of androgen levels in elderly men and its clinical and therapeutic implications. Endocr Rev. 2005; 26(6):833-876.

8. Harman SM, Metter EJ, Tobin JD, Pearson J, Blackman MR. Longitudinal effects of aging on serum total and free testosterone levels in healthy men. Baltimore Longitudinal Study of Aging. J Clin Endocrinol Metab. 2001;86(2):724-731.

9. Feldman HA, Longcope C, Derby CA, et al. Age trends in the level of serum testosterone and other hormones in middle-aged men: longitudinal results from the Massachusetts male aging study. J Clin Endocrinol Metab. 2002;87(2):589-598.

10. Araujo AB, Esche GR, Kupelian V, et al. Prevalence of symptomatic androgen deficiency in men. J Clin Endocrinol Metab. 2007;92(11): 4241-4247.

11. Wang C, Nieschlag E, Swerdloff R, et al. Investigation, treatment and monitoring of late-onset hypogonadism in males. Int J Androl. 2009;32(1):1-10.

12. Al-Futaisi AM, Al-Zakwani IS, Almahrezi AM, Morris D. Subcutaneous administration of testosterone. A pilot study report. Saudi Med J. 2006;27:1843-1846.

13. Szeinbach SL, Seoane-Vazquez E, Summers KH. Development of a men's Preference for Testosterone Replacement Therapy (P-TRT) instrument. Patient Prefer Adherence. 2012;6:631-641.

14. Gagnier JJ, Kienle G, Altman DG, Moher D, Sox H, Riley D; CARE group The CARE guidelines: consensus-based clinical case reporting guideline development. BMJ Case Rep. 2013;2013.

15. Gagnier JJ, Kienle G, Altman DG, Moher D, Sox H, Riley D; the CARE group. The CARE guidelines: consensus-based clinical case report guideline development. J Clin Epidemiol. Epub September 11, 2013.

16. Dandona P, Rosenberg MT. A practical guide to male hypogonadism in the primary care setting. Int J Clin Pr. 2010;64(6):682-696.

17. Griffin JE, Wilson JD. Disorders of the testis and male reproductive tract. In: Larsen PR, Kronenberg HM, Melmed S, Polonsky KS, editors. William's Textbook of Endocrinology. 10th ed. New York: WB Saunders; 2003:709-770.

18. Ohl DA, Quallich SA. Clinical hypogonadism and androgen replacement therapy: an overview. Urol Nurs. 2006;26(4):253-259, 269; quiz 260.

19. Hall JE. Reproductive and Hormonal Functions of the Male. In: Guyton and Hall Textbook of Medical Physiology. 12th ed. New York: Elsevier; 2010.

20. Hayes FJ, Seminara SB, Decruz S, Boepple PA, Crowley WF. Aromatase inhibition in the human male reveals a hypothalamic site of estrogen feedback. J Clin Endocrinol Metab. 2000;85(9):3027-3035.

21. Falahati-Nini A, Riggs BL, Atkinson EJ, O'Fallon WM, Eastell R, Khosla S. Relative contributions of testosterone and estrogen in regulating bone resorption and formation in normal elderly men. J Clin Invest. 2000;106(12):1553-1560.
22. Khosla S, Melton LJ, Atkinson EJ, O'Fallon WM, Klee GG, Riggs BL. Relationship of serum sex steroid levels and bone turnover markers with bone mineral density in men and women: a key role for bioavailable estrogen. J Clin Endocrinol Metab. 1998;83(7):2266-2274.

23. Tracz MJ, Sideras K, Boloña ER, et al. Testosterone use in men and its effects on bone health. A systematic review and meta-analysis of randomized placebo-controlled trials. J Clin Endocrinol Metab. 2006;91(6):2011-2016.

24. Ferlin A, Selice R, Carraro U, Foresta C. Testicular function and bone metabolism - beyond testosterone. Nat Rev Endocrinol. 2013;9(9): 548-554.

25. Sinnesael M, Claessens F, Boonen S, Vanderschueren D. Novel insights in the regulation and mechanism of androgen action on bone. Curr Opin Endocrinol Diabetes Obes. 2013;20(3):240-244.

26. Rodriguez-Tolrà J, Torremadé J, di Gregorio S, Del Rio L, Franco E. Effects of testosterone treatment on bone mineral density in men with testosterone deficiency syndrome. Andrology. 2013;1(4): $570-575$.

27. Meinhardt U, Mullis PE. The essential role of the aromatase/p450arom. Semin Reprod Med. 2002;20(3):277-284.

28. Vermeulen A, Kaufman JM, Goemaere S, van Pottelberg I. Estradiol in elderly men. Aging Male. 2002;5(2):98-102.

29. Mauvais-Jarvis F, Clegg DJ, Hevener AL. The role of estrogens in control of energy balance and glucose homeostasis. Endocr Rev. 2013; 34(3):309-338.

30. Chrousos GP. Stress and disorders of the stress system. Nat Rev Endocrinol. 2009;5(7):374-381.

31. Blick G, Khera M, Bhattacharya RK, Kushner H, Miner MM. Testosterone replacement therapy in men with hypogonadism and HIV/AIDS: results from the TRiUS registry. Postgrad Med. 2013;125(2):19-29.

32. Yeap BB, Alfonso H, Chubb SAP, et al. Reference ranges and determinants of testosterone, dihydrotestosterone, and estradiol levels measured using liquid chromatography-tandem mass spectrometry in a population-based cohort of older men. J Clin Endocrinol Metab. 2012;97(11):4030-4039.

33. Longcope C, Kato T, Horton R. Conversion of blood androgens to estrogens in normal adult men and women. J Clin Invest. 1969;48(12): 2191-2201.

34. Finkelstein JS, Lee H, Burnett-Bowie S-AM, et al. Gonadal steroids and body composition, strength, and sexual function in men. $N$ Engl J Med. 2013;369(11):1011-1022.

35. Simanainen U, Brogley M, Gao YR, et al. Length of the human androgen receptor glutamine tract determines androgen sensitivity in vivo. Mol Cell Endocrinol. 2011;342(1-2):81-86.

36. Wang C, Swerdloff R, Kipnes M, et al. New testosterone buccal system (Striant) delivers physiological testosterone levels: pharmacokinetics study in hypogonadal men. J Clin Endocrinol Metab. 2004;89(8):3821-3829.

37. Gooren LJ. Advances in testosterone replacement therapy. Front Horm Res. 2009;37:32-51.

38. Morales A, Johnston B, Heaton JPW, Lundie M. Testosterone supplementation for hypogonadal impotence: assessment of biochemical measures and therapeutic outcomes. J Urol. 1997;157(3):849-854.

39. Snyder PJ, Lawrence DA. Treatment of male hypogonadism with testosterone enanthate. J Clin Endocrinol Metab. 1980;51(6):1335-1339.

40. Smith RP, Khanna A, Coward RM, et al. Factors influencing patient decisions to initiate and discontinue subcutaneous testosterone pellets (testopel) for treatment of hypogonadism. J Sex Med. 2013;10(9): 2326-2333.

41. Ullah MI, Washington T, Kazi M, Tamanna S, Koch CA. Testosterone deficiency as a risk factor for cardiovascular disease. Horm Metab Res. 2011;43(3):153-164.

42. Koch CA, Zitzmann M. Testosterone deficiency or male hypogonadism. In: Koch CA, Chrousos GP, editors. Contemporary Endocrinology: Endocrine Hypertension. New York: Springer; 2013.

43. Basaria S, Dobs AS. New modalities of transdermal testosterone replacement. Treat Endocrinol. 2003;2(1):1-9. 
44. Gooren LJ, Bunck MC. Androgen replacement therapy: present and future. Drugs. 2004;64(17):1861-1891.

45. Swerdloff RS, Wang C. Androgens and the ageing male. Best Pract Res Clin Endocrinol Metab. 2004;18(3):349-362.

46. Bouloux P. Testim 1\% testosterone gel for the treatment of male hypogonadism. Clin Ther. 2005;27(3):286-298.

47. Hong BS, Ahn TY. Recent trends in the treatment of testosterone deficiency syndrome. Int J Urol. 2007;14(11):981-985.

48. Jones TH. Testosterone replacement therapy. Br J Hosp Med (Lond). 2007;68(10):547-553.

49. Srinivas-Shankar U, Sharma D. Testosterone treatment in elderly men. Adv Ther. 2009;26(1):25-39.

50. Corona G, Rastrelli G, Forti G, Maggi M. Update in testosterone therapy for men. J Sex Med. 2011;8(3):639-654; quiz 655.

51. Giagulli VA, Triggiani V, Corona G, et al. Evidence-based medicine update on testosterone replacement therapy (TRT) in male hypogonadism: focus on new formulations. Curr Pharm Des. 2011;17(15): 1500-1511.

52. Abadilla KA, Dobs AS. Topical testosterone supplementation for the treatment of male hypogonadism. Drugs. 2012;72(12): 1591-1603.

53. Dinsmore WW, Wyllie MG. The long-term efficacy and safety of a testosterone mucoadhesive buccal tablet in testosterone-deficient men. BJU Int. 2012;110(2):162-169.

54. Jenerowicz D, Polańska A, Olek-Hrab K, Silny W. Skin hypersensitivity reactions to transdermal therapeutic systems - still an important clinical problem. Ginekol Pol. 2012;83(1):46-50.

55. Foco A, Hadziabdic J, Becic F. Transdermal drug delivery systems. Med Arch. 2004;58(4):230-234.

56. Cunningham GR, Cordero E, Thornby JI. Testosterone replacement with transdermal therapeutic systems. Physiological serum testosterone and elevated dihydrotestosterone levels. JAMA. 1989;261(17): 2525-2530.

57. Eisenegger C, Von Eckardstein A, Fehr E, Von Eckardstein S. Pharmacokinetics of testosterone and estradiol gel preparations in healthy young men. Psychoneuroendocrinology. 2013;38:171-178.

58. Bhasin S, Cunningham GR, Hayes FJ, et al; Task Force, Endocrine Socity. Testosterone therapy in men with androgen deficiency syndromes: an Endocrine Society clinical practice guideline. J Clin Endocrinol Metab. 2010;95(6):2536-2559.

59. Wang C, Ilani N, Arver S, McLachlan RI, Soulis T, Watkinson A. Efficacy and safety of the 2\% formulation of testosterone topical solution applied to the axillae in androgen-deficient men. Clin Endocrinol. 2011;75(6):836-843.

60. Abadilla KA, Dobs AS. Topical testosterone supplementation for the treatment of male hypogonadism. Drugs. 2012;72(12):1591-1603.

61. Dobs AS, McGettigan J, Norwood P, Howell J, Waldie E, Chen Y. A novel testosterone $2 \%$ gel for the treatment of hypogonadal males. J Androl. 2012;33(4):601-607.

62. McNicholas T, Ong T. Review of Testim gel. Expert Opin Pharmacother. 2006;7(4):477-484.

63. Marbury T, Hamill E, Bachand R, Sebree T, Smith T. Evaluation of the pharmacokinetic profiles of the new testosterone topical gel formulation, Testim, compared to AndroGel. Biopharm Drug Dispos. 2003;24(3):115-120.

64. Amory JK, Watts NB, Easley KA, et al. Exogenous testosterone or testosterone with finasteride increases bone mineral density in older men with low serum testosterone. J Clin Endocrinol Metab. 2004;89(2):503-510.

65. Calof OM, Singh AB, Lee ML, et al. Adverse events associated with testosterone replacement in middle-aged and older men: a meta-analysis of randomized, placebo-controlled trials. J Gerontol A Biol Sci Med Sci. 2005;60(11):1451-1457.

66. Fernández-Balsells MM, Murad MH, Lane M, et al. Clinical review 1: Adverse effects of testosterone therapy in adult men: a systematic review and meta-analysis. J Clin Endocrinol Metab. 2010;95(6): 2560-2575.
67. Shabsigh R, Crawford ED, Nehra A, Slawin KM. Testosterone therapy in hypogonadal men and potential prostate cancer risk: a systematic review. Int J Impot Res. 2009;21(1):9-23.

68. Burnett AL, Kan-Dobrosky N, Miller MG. Testosterone replacement with $1 \%$ testosterone gel and priapism: no definite risk relationship. J Sex Med. 2013;10(4):1151-1161.

69. Morrison BF, Reid M, Madden W, Burnett AL. Testosterone replacement therapy does not promote priapism in hypogonadal men with sickle cell disease: 12-month safety report. Andrology. 2013;1(4):576-582.

70. Francomano D, Ilacqua A, Bruzziches R, Lenzi A, Aversa A. Effects of 5-year treatment with testosterone undecanoate on lower urinary tract symptoms in obese men with hypogonadism and metabolic syndrome. Urology. Epub October 15, 2013.

71. Yassin D-J, El Douaihy Y, Yassin AA, Kashanian J, Shabsigh R, Hammerer PG. Lower urinary tract symptoms improve with testosterone replacement therapy in men with late-onset hypogonadism: 5-year prospective, observational and longitudinal registry study. World J Urol. Epub October 18, 2013.

72. Accessdata FDA. Available at: http://www.accessdata.fda.gov/drugsatfda_docs/label/2002/21454 lbl.pdf. Accessed November 10, 2013.

73. Kunz GJ. Virilization of young children after topical androgen use by their parents. Pediatrics. 2004;114(1):282-284.

74. Bhasin S, Cunningham GR, Hayes FJ, et al. Testosterone therapy in adult men with androgen deficiency syndromes: an endocrine society clinical practice guideline. J Clin Endocrinol Metab. 2006;91(6):1995-2010.

75. Di Luigi L, Sgrò P, Aversa A, et al. Concerns about serum androgens monitoring during testosterone replacement treatments in hypogonadal male athletes: a pilot study. $J$ Sex Med. 2012;9(3):873-886.

76. Wang C, Swerdloff RS, Iranmanesh A, et al; Testosterone Gel Study Group. Transdermal testosterone gel improves sexual function, mood, muscle strength, and body composition parameters in hypogonadal men. J Clin Endocrinol Metab. 2000;85(8):2839-2853.

77. Saad F, Aversa A, Isidori AM, Zafalon L, Zitzmann M, Gooren L. Onset of effects of testosterone treatment and time span until maximum effects are achieved. Eur J Endocrinol. 2011;165(5):675-685.

78. Miner MM, Bhattacharya RK, Blick G, Kushner H, Khera M. 12-Month observation of testosterone replacement effectiveness in a general population of men. Postgrad Med. 2013;125(2):8-18.

79. Heufelder AE, Saad F, Bunck MC, Gooren L. Fifty-two-week treatment with diet and exercise plus transdermal testosterone reverses the metabolic syndrome and improves glycemic control in men with newly diagnosed type 2 diabetes and subnormal plasma testosterone. J Androl. 2009;30(6):726-733.

80. Hijazi RA, Cunningham GR. Andropause: is androgen replacement therapy indicated for the aging male? Annu Rev Med. 2005;56:117-137.

81. Malkin CJ, Pugh PJ, Jones RD, Kapoor D, Channer KS, Jones TH. The effect of testosterone replacement on endogenous inflammatory cytokines and lipid profiles in hypogonadal men. $J$ Clin Endocrinol Metab. 2004;89(7):3313-3318.

82. Ginzburg E, Klimas N, Parvus C, et al. Long-term safety of testosterone and growth hormone supplementation: a retrospective study of metabolic, cardiovascular, and oncologic outcomes. J Clin Med Res. 2010;2(4):159-166.

83. Emmelot-Vonk MH, Verhaar HJJ, Nakhai Pour HR, et al. Effect of testosterone supplementation on functional mobility, cognition, and other parameters in older men: a randomized controlled trial. JAMA. 2008;299:39-52.

84. Wang C, Swerdloff RS, Iranmanesh A, et al. Effects of transdermal testosterone gel on bone turnover markers and bone mineral density in hypogonadal men. Clin Endocrinol. 2001;54(6):739-750.

85. Bhattacharya RK, Khera M, Blick G, Kushner H, Nguyen D, Miner MM. Effect of 12 months of testosterone replacement therapy on metabolic syndrome components in hypogonadal men: data from the Testim Registry in the US (TRiUS). BMC Endocr Disord. 2011;11(1):18.

86. Guo W, Bachman E, Li M, et al. Testosterone administration inhibits hepcidin transcription and is associated with increased iron incorporation into red blood cells. Aging Cell. 2013;12(2):280-291. 
87. Marchioli R, Finazzi G, Specchia G, et al; CYTO-PV Collaborative Group. Cardiovascular events and intensity of treatment in polycythemia vera. N Engl J Med. 2013;368(1):22-33.

88. Spivak JL. Polycythemia vera, the hematocrit, and blood-volume physiology. N Engl J Med. 2013;368(1):76-78.

89. Wells RE, Merrill EW. Influence of flow properties of blood upon viscosity-hematocrit relationships. J Clin Invest. 1962;41: 1591-1598.
90. Schoenfeld MJ, Shortridge E, Cui Z, Muram D. Medication adherence and treatment patterns for hypogonadal patients treated with topical testosterone therapy: a retrospective medical claims analysis. J Sex Med. 2013;10(5):1401-1409.

91. Grober ED, Khera M, Soni SD, Espinoza MG, Lipshultz LI. Efficacy of changing testosterone gel preparations (Androgel or Testim) among suboptimally responsive hypogonadal men. Int J Impot Res. 2008;20(2):213-217.

\section{Publish your work in this journal}

Drug Design, Development and Therapy is an international, peerreviewed open-access journal that spans the spectrum of drug design and development through to clinical applications. Clinical outcomes, patient safety, and programs for the development and effective, safe, and sustained use of medicines are a feature of the journal, which has also been accepted for indexing on PubMed Central. The manuscript management system is completely online and includes a very quick and fair peer-review system, which is all easy to use. Visit http://www.dovepress.com/testimonials.php to read real quotes from published authors.

Submit your manuscript here: http://www.dovepress.com/drug-design-development-and-therapy-journal 